\section{Bright spark of the electric age}

Willem Hackmann

Ferranti and the Britlsh Electrical Industry, 1864-1940. By J. F. Wilson. Manchester University Press: 1991. Pp.165. £12.95. Published by St Martins Press in the United States, $\$ 24.95$.

WHEN Sebastian Ziani de Ferranti died on 13 January 1930 , at the age of 65 , the British electrical industry lost one of its most respected figures. He combined his family's interest in art (his father settled in Liverpool as a pioneer photographer) with a childhood fascination for technology. His parents fostered this interest with books like Samual Smiles' Life of the Stephensons.

Indeed, Ferranti's own life seems straight from the pages of one of Smiles' popular victorian biographies on notable engineers. His teenage bible was Ganot's highly readable Treatise on Physics, which was full of the technological marvels of the day. It also contained one of the most detailed descriptions of the theory of electromagnetism available in the $1870 \mathrm{~s}$, totally misunderstood by the young Ferranti, as he wrote to his parents that he was in the process of inventing a perpetual motion machine. His lack of academic application (as shown by his quaint phonetic spelling) must have been something of a headache to the teachers of his Catholic school, St. Augustine's at Ramsgate, but the institution was liberal enough to allow him to follow his technical bent. (When I went to the same school in the mid-1950s, Ferranti had become a shadowy memory. Like him, I was given the key to the well-equipped laboratory - much of it from Ferranti's days - so that I could follow my own interests, but I am afraid that is where the similarity ends.) Ferranti was imbued strongly with the belief of his age that science-based technology would be a 'blessing to the world'. He had supreme confidence both in himself (a very victorian virtue) and in the role electricity would play in the modern world. Throughout his career as an electrical manufacturer, virtually from the birth of the industry in 1882 to the implementation of the 1926 Electricity (Supply) Act, he pursued the goal of the 'all electric' age.

What makes Wilson's book different from previous biographies is that it sets Ferranti's career against the economic background. Indeed, this is as much a business history as a biography, and closely follows the intention of the series of which this volume is a part, to illuminate the role of businessmen and business institutions in forming the modern social fabric. Ferranti was deeply involved both in the development of an efficient supply industry and in the establishment of a viable electrical-engineering industry. These motivating forces were clearly illustrated in all he did, from his construction of the world's first modern power station at Deptford in the late 1880 s to the emergence of Ferranti Limited as one of the most progressive British electrical firms.

One of Wilson's aims was to examine, in the light of Ferranti's career, the common stereotype of the victorian and edwardian entrepreneur as being generally ignorant of matters scientific (because of a supposedly classical public-school education), failing to exploit products based on the new technologies, and being unwilling to invest in the latest efficient mass-production techniques. Ferranti certainly exhibits none of these faults, which allegedly started Britain's decline as a world economic power. As an engineer he was innovative, forward-looking and quick to exploit (and improve on) good having small local stations supplying lowvoltage direct current. Instead, Ferranti argued that the country should be served by a system of large stations with easy access for their fuel (coal), supplying alternating current at very high pressure which was stepped down at local stations.

The 'Battle of the Systems' was ultimately resolved in Ferranti's favour with the formation of the National Grid, but at the time Deptford became a very expensive failure because of government legislation in favour of local supply systems. The technical problems were enormous. For instance, no tools were big enough to construct the huge alternators so these had to be constructed in house. The lathe required to turn the main shaft was of the same dimension as that used for turning a 100-ton gun at Woolwich. In May 1891, the project to construct the giant

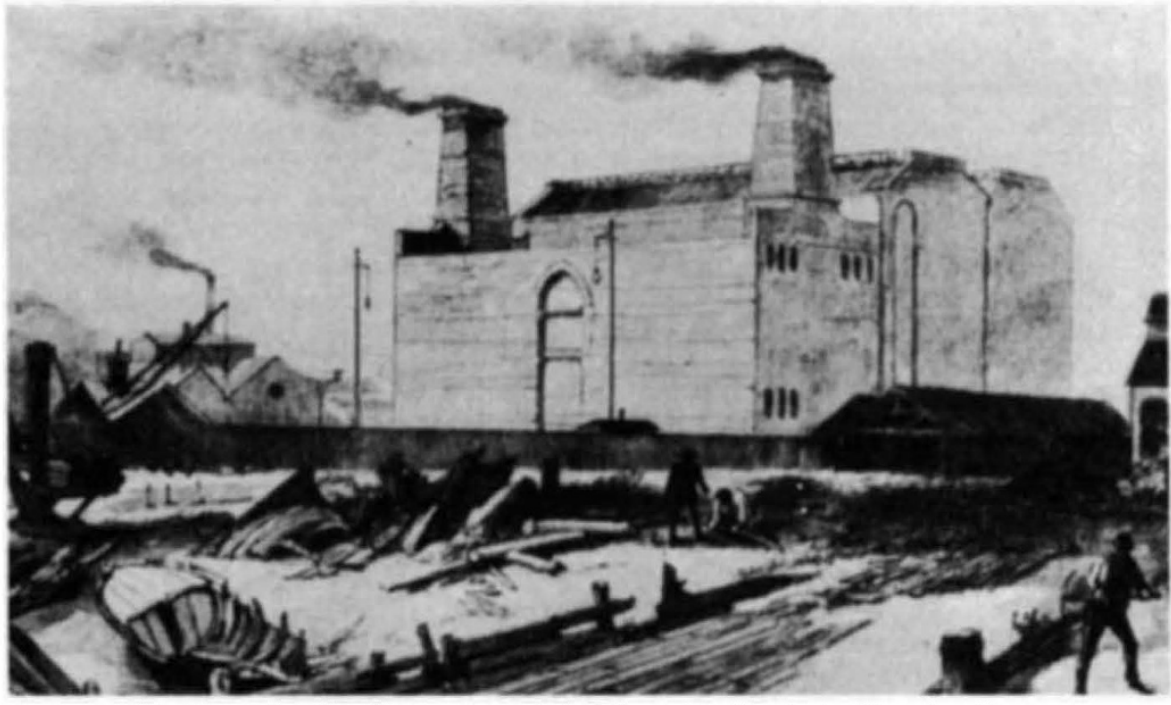

Sketch of the Deptford power station from the Illustrated London News.

ideas. His 200 or so patents on such diverse mechanisms as alternators, transformers, arc lamps, electrical supply meters, high-voltage cables, fuses, switchgear, an electrical furnace, a high-temperature steam turbine, stop valves and a high-speed cotton spinning frame, testify to this. Not all these inventions bore fruit, for a variety of reasons. As a businessman he was conservative in financial and administrative matters and did not accept advice easily. This tendency was in part responsible for the series of financial crises that affected his business dealings, and which are well described in this book. It also constantly weakened his ability to stand in competition with such giants as the German AEG or the American General Electric Company, and brought him, in 1903 , to the brink of ruin. In this respect he was perhaps also typical of his generation.

One of the most endearing aspects of his character was his sheer enthusiasm, which he could communicate to others. Who else could have persuaded hard-headed businessmen to invest in the construction of the largest power station in the world at that time. Deptford was 40 years before its time and ran counter to the accepted wisdom of
10,000 -volts, 10,000 horse-power steam engines and alternators was abandoned. Had they been completed, each alternator would have weighed nearly 500 tons, with the armature and shaft accounting for 225 tons. Edison was impressed when he visited the site in 1889, and congratulated the 'Michaelangelo' of Deptford but disagreed with the project.

Wilson concludes that Ferranti's problem lay in matching his ideas to an unresponsive environment. He was not a commercial engineer and his company only began to exploit his products successfully after chartered accountants joined the board. Nor was he good with labour relations (an aspect of his character that could have been developed further), but he did work hard for standardization in the electrical industry. His work has certainly touched all our lives, not least the small air turbines developed for cotton spinning, which later found application in dentists' drills.

Willem Hackmann is at the Museum of the History of Science, University of Oxford, Old Ashmolean Building, Broad Street, Oxford OX1 3AZ, UK. 